\title{
二眼式立体映像の呈示方式によって生じるアーチファクトと 生理・心理的影響*
}

\author{
吉竹淳樹**，金 相賢**，盛川浩志**，三家礼子**，河合隆史**
}

\begin{abstract}
In this study, a basic examination on psycho-physiological effects by display systems of stereoscopic 3D images (3D) was carried out. Time-multiplexing and spatial-multiplexing systems were focused as major 3D display systems for consumer use. Characteristic artifacts of each system were extracted, and their psychophysiological effects were evaluated.

Concretely, phantom array, pseudo parallax and flicker from time-multiplexing system, and binocular-rivalry, pseudo parallax and reduction of resolution from spatial-multiplexing system were defined as characteristic artifacts and represented by simple visual stimuli for experiments. From the results of the experiments, inductions of the artifacts were confirmed, and the psycho-physiological responses of the participants were changed by the intensity or combination of the artifacts. In addition, individual difference of the artifacts in the psycho-physiological effects and the interactions, and possibilities to reduce the effects by presentation methods were suggested.
\end{abstract}

本研究では，二眼式立体映像の呈示方式が与える生体影響に関して，基礎的な検討を行った，家庭向けの 主要な呈示方式として，時間多重方式と空間多重方式に着目し，各方式に打いて特有のアーチファクトを抽 出し，それらの生理・心理的な影響について評価した。具体的に，時間多重方式ではファントムアレイ，偽 視差，フリッカ，空間多重方式では，視野闘争，偽視差，解像度低下というアーチファクトを定義し，それ らの強度や随伴の容易な単純刺激を用いて実験を行った。結果から，実験刺激によるアーチファクトの生起 が確認され，それらが生理・心理的な影響を与え得ることが分かったそそして，アーチファクトの種類によ る影響の差異や相互作用と同時に，呈示方法の工夫によりアーチファクトを軽減する可能性も示唆された. (キーワード：立体映像，時間多重方式，空間多重方式，アーチファクト，眼精痏労)

\section{1.はじめに}

近年，二眼式立体映像（3D）技術が飛躍的に向上し， 映画館からモバイル端末に至るまで，広範囲にわたって 利活用されている。また，3D対応テレビや3D対応ゲー ム機などが次々と市販され，多様な3Dコンテンッが継続 的に制作・流通されるなど，3Dは日常生活において身近 な存在になってきた。しかし, 現状の3Dの多面的な動向 は, 世界規模で急速に展開しており, 結果として3Dが与 える生体影響の検討が未だ十分になされていないという 問題が顕在化している。特に，3Dを観察することで生じ る視覚負担は，常に問題として認識されており，例えば

\footnotetext{
*受付：2012年1月20日 受理：2012年5月28日

**早稲田大学理工学術院

Faculty of Science and Engineering, Waseda University
}

電子情報技術産業協会の「3次元映像に関するガイドライ ン試案11」や3Dコンソーシアムの「3DC安全ガイドライ ン2)」など，3Dの安全性に関するガイドラインも提案さ

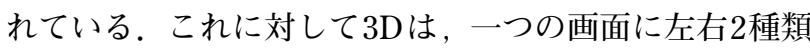
の映像を呈示するという，一種の矛盾を解決するために， 方式毎にトレードオフを有していることが知られている. しかしながら，呈示方式の違いによって，視聴者に与え る生体影響にどのような差異があるのかは未知な点が多 い，そこで本研究では，家庭向けの主要な呈示方式であ る時間多重方式と空間多重方式に着目し，それぞれのア 一チファクトを定義すると同時に，その生体影響を明ら かにすることを目的として，基礎的な検討を行った。こ こで，アーチファクトとは一般に「人工物」を意味する が, 本研究では3Dの呈示方式に起因した，本来，意困せ ずに生じる，望ましくない知覚現象を指す。こうしたア 一チファクトは, 3Dの体験品質，ひいては生体に対して 何らかの影響を及ぼす可能性があると考えられる。 


\section{2. 時間多重方式とアーチファクト}

われわれは，両眼に呈示された映像に時間的なずれが 生じていても, 一定範囲内であれば立体視可能であるこ とが知られている3 ${ }^{3)}$. 時間多重方式は，こうした視覚的な 特性を利用したものであり, 左右の映像を一定周期で交 互に切り替えて呈示し，それと同期してメガネに付加さ れた液晶シャッタを開閉させることで, 映像を左右眼に 分割して呈示する。しかしながら, 左右のシャッタを交 互に開閉することで立体視を成立させているため, 実際 には点滅している映像を交互に観察していることになり， このことが特有のアーチファクトを生じさせる.

本研究では, 時間多重方式のアーチファクトとして, ファントムアレイ, 偽視差, フリッカに着目した。

\section{2-1. ファントムアレイ}

われわれは, 移動する視標を観察する際, 視線を合わ せるよう眼球を動かしている. 眼球運動のうち, 移動す る視標を追従する動きを随従運動, 視線が視標に停留し, 次の注視点に向けて急速に移動する動きをサッカード (跳躍運動) という. サッカードの最中に, ある一点で連 続して点滅する視標が呈示された場合, サッカードをし た方向とは逆の方向に, 順次に視標が点滅する感覚が生 じる (図1)。この現象をファントムアレイといゔ). 時間 多重方式では, 上述したように, シャッタの切り替えに よって左右像を分離しているために, 高速で点滅する映 像を観察することとなり，ファントムアレイを知覚する 場合がある。

\section{2-2. 偽視差}

偽視差とは, 本来, 視覚刺激に含まれていない両眼視 差が, 擬似的に呈示されることを指す。時間多重方式で は, 水平方向に移動する視標を観察すると, 両眼視差が 含まれていないにも関わらず, 視標が画面の前後に知覚 される場合がある。これは, 液晶シャッタの切り替えに よって, 左右眼に視標が呈示されるタイミングに微小な 時間差が生じ，その間に移動した視標の距離が視差とし て知覚されるためと考えられる。したがって, 視標の水 平移動が高速なほど, 偽視差の量も増加する。偽視差は, 左右眼に時間差をもって視標を呈示した際に, 水平方向に 移動する視標が奥行き方向にも回転して知覚されるとい うMach-Dvorak現象5) の機序と同様と考えられる (図2).

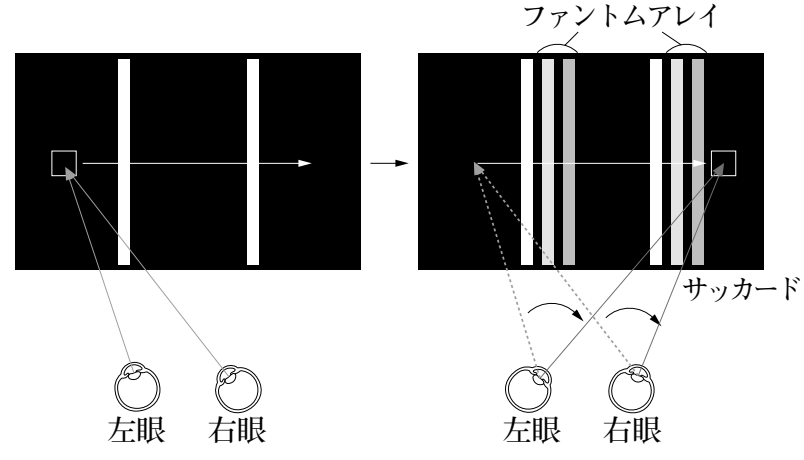

図1 ファントムアレイのイメージ図

Fig. 1 Phantom array in time-multiplexing system.

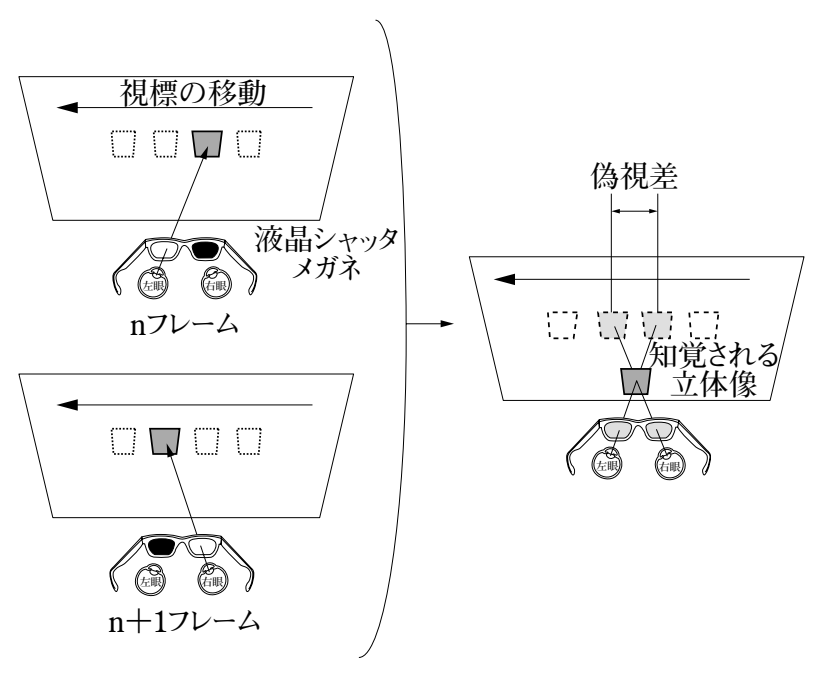

図2 時間多重方式における偽視差のイメージ四

Fig. 2 Pseudo parallax in time-multiplexing system.

\section{2-3. フリッカ}

フリッカとは, 光の点滅による細かいちらつきのこと であり，単位時間あたりの画面のリフレッシュレートが 低いと，画面のちらつきを感じる．概ねリフレッシュレ 一トが $60 \mathrm{~Hz}$ 以下で，フリッカが知覚されることが知られ ている ${ }^{3)}$. 現在の家庭用 $3 \mathrm{D}$ テレビでは, 臨界フリッカ周 波数を超える $120 \mathrm{~Hz}$ 以上の周期で液晶シャッタが駆動す るよう設計することで, フリッカが感じられないよう配 慮されている。しかしながら, フリッカによる影響を完 全に否定することはできないため, これも時間多重方式 に特有なアーチファクトの一つとして扱うこととした.

\section{3. 空間多重方式とアーチファクト}

空間多重方式は, ある一方向に振動する光のみを透過 する偏光フィルタを，画面とメガネにそれぞれ配置する ことで，左右眼に分割する方式である。一般に，空間多 
重方式では, 液晶パネルの水平ラインピッチに合わせて, 1ライン毎に振動方向の異なる偏光フィルタが貼付されて いる. 1ライン毎に左右像を呈示することで，一つの画面 に左右二つの映像の多重化が可能になる半面, 解像度の 低下をはじめとした特有のアーチファクトが発生するこ とも知られている。本研究では, 空間多重方式に特有の アーチファクトとして, 視野闘争, 偽視差, 解像度の低 下に着目した。

\section{3-1. 視野闘争}

われわれは, 左右の網膜像を一つの立体像として融像 しているが，それらが左右で極端に異なる場合に，一つ の対象として融像することができず, 左右像が交互に知 覚される。この状態を, 視野闘争という。上述のように, 空間多重方式では，1ライン毎に左右の映像を交互に配置 することから, どちらか一方の水平1ラインのみに呈示さ れた情報は, 他方の眼で知覚されない。したがって, 文 字や空間周波数が高い刺激などでは, 両眼の網膜像差が 顕著となり視野闘争を生じる場合がある.

\section{3-2. 偽視差}

本来, 視覚刺激に含まれていない両眼視差が, 擬似的 に呈示される点では時間多重方式と同様であるが，空間 多重方式では発生条件が異なる。具体的に, 左右の映像 が1フレームにホールドして呈示されるため, 時間順次的 に左右の映像が記録された映像の場合, 同一フレーム内 の左右の映像間に記録された周期分の微小な時間差が生 じる。このことは, 水平方向に移動する視標が呈示され た場合に視差が含まれることを意味している，再生時の 時間差に起因するMach-Dvorak現象に対して，ここでは

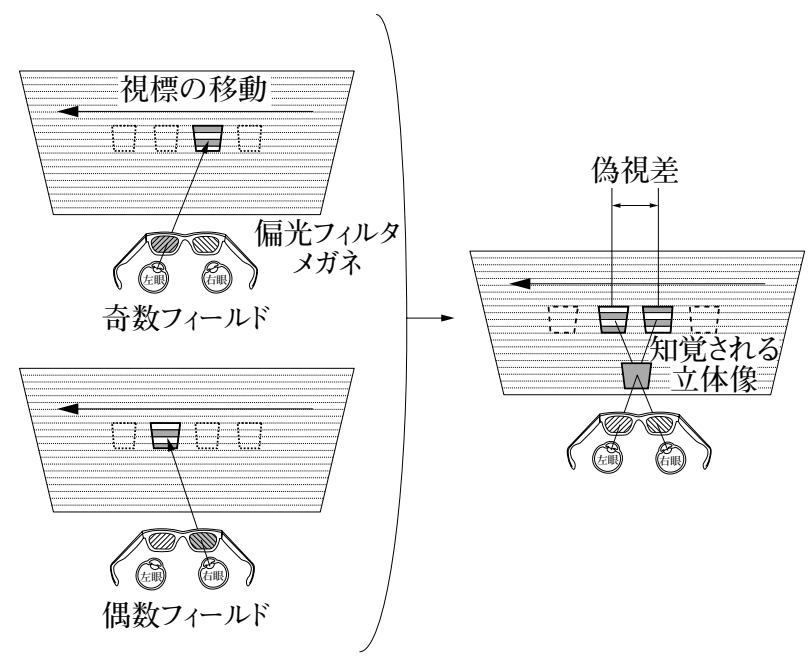

図3 空間多重方式における偽視差のイメージ四

Fig. 3 Pseudo parallax in spatial-multiplexing system.
記録時の左右の映像での時間差が原因である（図3）.

\section{3-3. 解像度低下}

空間多重方式では，画面の水平1ライン毎に左右の映像 を交互に配置するため, 垂直方向の解像度が半分となる. 解像度の低下により，鮮明度やコントラストが減少し， 情報量だけでなく品質の低下も予想される。本研究では, こうした視覚情報の劣化もアーチファクトの一つとして 考えている.

\section{4. 実験 1 ：時間多重方式のアーチファクトの 評価}

\section{4-1. 方法}

時間多重方式のアーチファクトによる生体影響の評価 にあたって, 心理指標として眼精疲労の自覚症状を調査 した。鵜飼らによる質問紙6) を用い，刺激呈示前後に 28 項目の質問に対して7件法での回答を求め，刺激観察 前後の変化を明確化するために，項目毎の評定点を，以 下の変化率に換算して解析を行った。変化率が0ならば観 察前と同じであり, 変化率が 1 ならば観察前の 2 倍, 眼精 疲労に関する訴えが増えたことを意味する。

変化率 $=($ 刺激観察後の評定点一 刺激観察前の評定点) / （刺激観察前の評定点）

また，刺激呈示後には，偽視差の強度を評価するため， 2Dで呈示された視標の立体感，つまり画面の前後に再生 されている感覚について，1（ほとんど感じない）から5 （とても感じる）の5件法で回答を求め, 各参加者の評定 の平均値を評定平均值とし, 解析を行った。加えて, 各 アーチファクトの生起を確認するため, 実験後に映像の 見え方や印象についてのインタビューを実施した。生理 指標では，刺激呈示前後に赤外線オプトメータ (SpeedyK, Right on）を用いて屈折值と調節微動を測定し，自覚 症状と同様に変化率に換算して解析を行った。また，呈 示中の前頭前野の脳血流の変化と心拍動を，簡易型光卜 ポグラフィ装置（NIRS：Near-infrared spectroscopy） （HOT121，日立製作所）を用いて測定した. NIRSは，へ モグロビンの種類によって，吸収する光の波長が異なる ことを利用し，血液量の変化を測定する．神経細胞が活 動すると，その周辺の血管が拡張して血流量が増加する ことから，血液中に含まれるへモグロビンの濃度変化を 計測することで, 脳の活性化状況をとらえることができ る. $3 \mathrm{D}$ 注視時の脳血流変化が $2 \mathrm{D}$ 映像に比較して増大し 


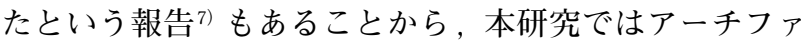
クトの多い映像ほど, 神経活動が活発化し, 脳への負担 が大きくなるとの仮説の基, 脳血流の測定を試みた。な お，NIRSを用いた測定では頭部での光の伝播経路が特定 できないため, 得られるへモグロビンの濃度変化のデー タは，計測開始時を基準とする相対的なデータである. また，この機器で計測される脳血流は, 総へモグロビン 量 (total-Hb) である.

実験の規模として，心理指標を測定した参加者が男女 28例 (平均23.8歳), 屈折值と調節微動を測定した参加者 が男女 20 例 (平均23.8歳), 脳血流と心拍動を測定した参 加者が男女8例（平均年齢26.0歳）であった。実験開始前 に，実験の趣旨や方法を説明し，理解・同意の上，実験 を実施した。刺激の呈示には，22亿ンチの液晶モニタ （SyncMaster 2233RZ，SAMSUNG）と液晶シャッタメガ ネ（3D Vision, nVIDIA）を用いた。モニタの解像度は $1680 \times 1050$ ピクセルであった，実験は暗室内で行い, 参加 者には眼の高さがスクリーンの中心になるよう椅子への 着席を求め，実験中は顎台を用いて頭部を固定した。こ のとき視距離は，600 mmになるように設定した（図4）。

刺激は，アーチファクトの生起や抑制を統制しやすい 単純図形で構成した。具体的に，黒い背景に横幅が視角 0.25 度の白色の垂直線を 2 本，画面の中心から左右に視角 で5度離れるよう，それぞれ配置した。視標は 1 ピクセル

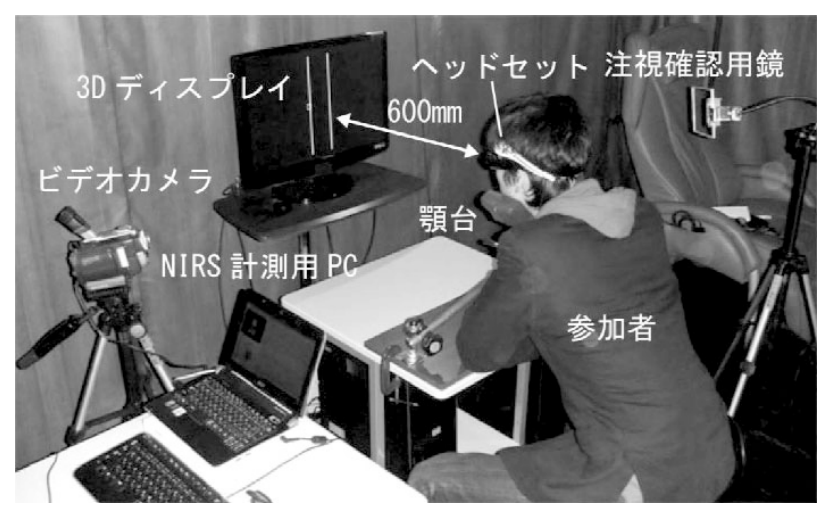

図4 実験の様子

Fig. 4 Layout of experiment.

表 1 時間多重方式の実験条件と3Dアーチファクト

Tab. 1 Experimental conditions and including 3D artifacts : time-multiplexing system.

\begin{tabular}{|c|c|c|c|c|c|}
\hline 時間多重 & 左右視標 & 視標速度 & ファントムレイ & 為視差 & フリッカ \\
\hline 条件1 & $\square \square$ & 20度/秒 & あり & あり & あり \\
\hline 条件2 & $\square \square$ & 5度/秒 & なし & あり & あり \\
\hline 条件 3 & $\square \square$ & 5度/秒 & なし & なし & あり \\
\hline 条件4 & $\square \square$ & 5度/秒 & なし & なし & なし \\
\hline
\end{tabular}

の白線で描画された正方形であり，一辺は視角で1度であ った。視標は，各条件で設定された速度で，画面の中央 から左右に視角 10 度分となる範囲を，連続的に水平往復 移動するものであり，呈示時間は5分間であった。

実験の条件は，視標の移動速度や呈示方法を変えるこ とで，アーチファクトの強度や種類を変化させた 4 条件と した（表1）。具体的に，条件1では，ファントムアレイ， 偽視差，フリッカの3種類のアーチファクトを含む刺激を 用意した．視標の速度を 20 度／秒にすることで，サッカ 一ドを誘発し，ファントムアレイの知覚と同時に，偽視 差の増強を意困した。さらに液晶シャッタの開閉による

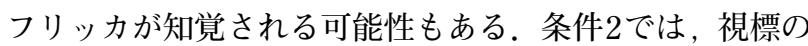
速度を随従運動の可能な 5 度/秒に設定することで，ファ ントムアレイを抑制し，偽視差の軽減を図った。条件3で は，前後のフレームから中間フレームを生成して呈示す ることで，時分割呈示によって生じる左右映像の時間差 を解消させ，偽視差の抑制を図った。条件 4 は，さらに液 晶シャッタの電源を切ることで，フリッカの知覚される 可能性も除去した統制条件とした。なお，実験の実施に おいては，試行の間に15分間以上の休息を設けて参加者 の状態を確認し，次の試行に影響がないよう配慮した。

\section{4-2. 結果}

刺激呈示後の眼精疲労の自覚症状について，条件別の 結果を図5に示した。実験条件と自覚症状を要因とした 2 要因の分散分析を行った結果，実験条件の主効果 $(\mathrm{p}<.05)$ ，自覚症状の主効果 $(\mathrm{p}<.01)$ ，交互作用 $(\mathrm{p}<.01)$ が認められた。下位検定の結果，条件1が他の 条件よりも上昇率が有意に高いことが分かった。また， 上昇率の高い自覚症状の項目として, 眼精疲労に関連す る「目が疲れている」「目がしみる」「目が乾いた感じが する」「目がちかちかする」「目がしょぼしょぼする」の

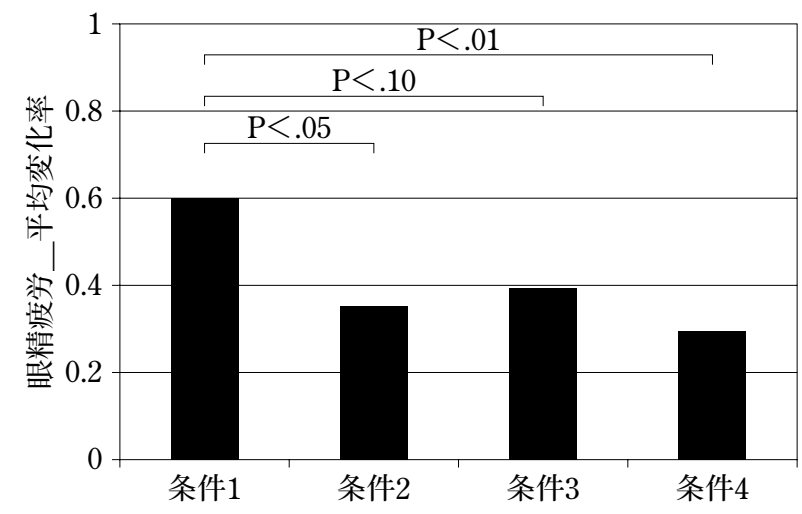

図5 時間多重方式における眼精疲労の自覚症状結果

Fig. 5 Result of visual fatigue subjective symptom : timemultiplexing system. 


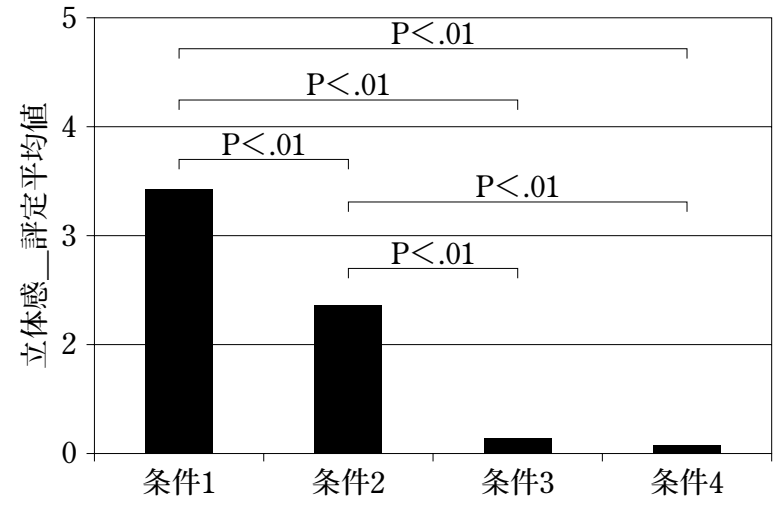

図6 時間多重方式における2D指標の立体感の結果

Fig. 6 Result of depth sensation : time-multiplexing system.

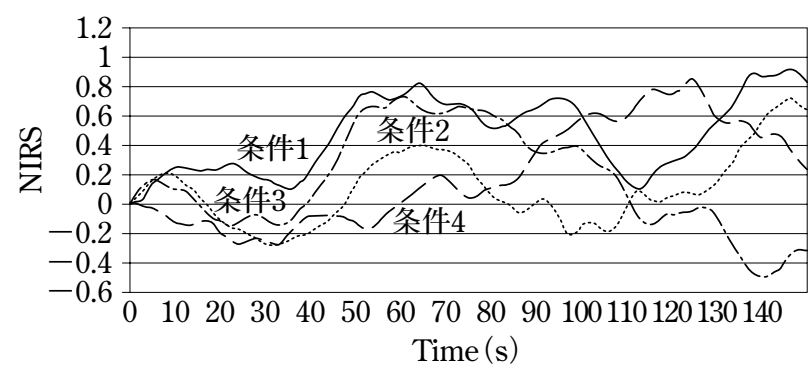

図7 時間多重方式におけるNIRS值の結果

Fig. 7 Result of NIRS value : time-multiplexing system.

5項目があげられた。さらに，2D視標の立体感による偽 視差の強度の結果を, 図6に示した。実験条件を要因とし た分散分析を行った結果，有意差が認められ $(\mathrm{p}<.01)$ ， 下位検定の結果，条件 1 と条件 2 の立体感が有意に高いこ とが分かった。

一方脳血流は, NIRSから得られるデータが相対的な変 化のため, 参加者間の単純な比較ができず，ノイズが発 生するという問題も有していることから，得られたデー タに対し次の処理を施した上で解析を行った。まず, 測 定した各データを参加者毎に標準化し，時系列データの 変動傾向を推定するトレンド解析》 と移動平均を用いて 平滑化した，さらに交差相関を求め条件間のずれを補正 し，刺激開始の值が0になるようにシフトすることで，条 件間で比較できるようにした。本論文では，これらの処 理後のデータをNIRS値として表す。図7に, 刺激呈示開 始から 150秒間のNIRS值の変動を示した。150秒を15秒 毎に分割した後，その区間におけるデータの平均值を算 出し，実験条件と測定時間を要因とした2要因の分散分析 を行った結果，実験条件の主効果（p<.05）が認められ た。下位検定の結果，条件 1 と条件 2 の間に有意な差が見 られた。拍動に対しても同様の処理を行い，心拍動值 として解析を行った（図8)。実験条件と測定時間を要因

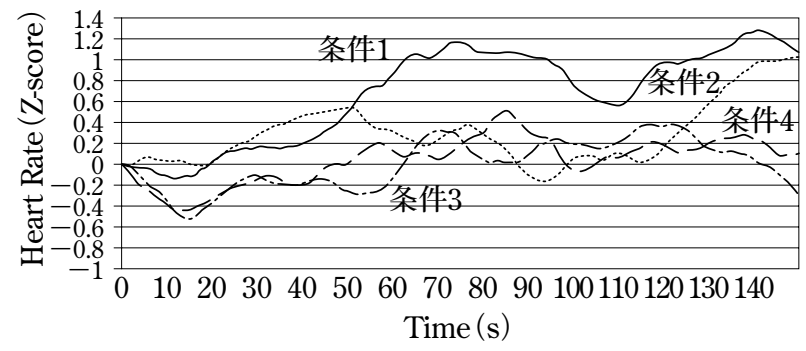

図8＼cjkstart時間多重方式における心拍動の結果

Fig. 8 Result of Heart Rate (Z-score) : time-multiplexing system.

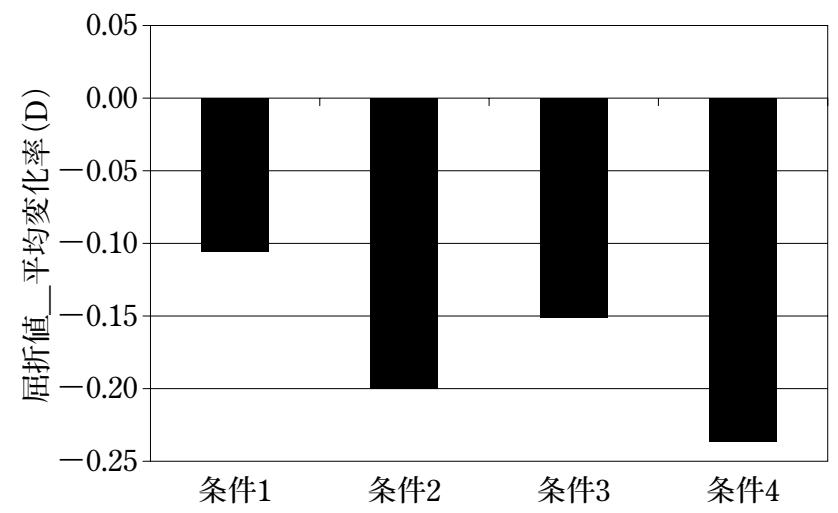

図9時間多重方式における屈折值の結果

Fig. 9 Result of refractive value : time-multiplexing system.

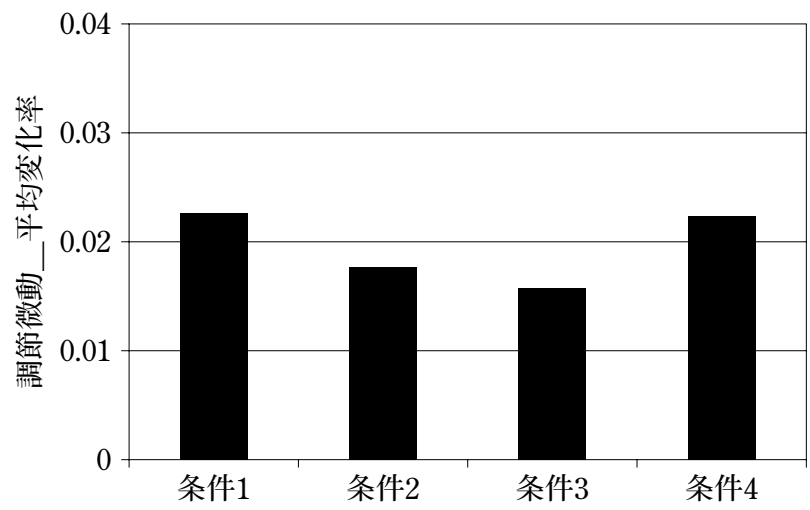

図 10 時間多重方式における調節微動の結果

Fig. 10 Result of accommodation value : time-multiplexing system.

とした 2 要因の分散分析を行った結果，実験条件の主効果 $(\mathrm{p}<.01)$ ，測定時間の主効果 $(\mathrm{p}<.01)$ が認められた。 下 位検定の結果，条件1が他の条件より有意に高いことが分 かった，屈折值と調節微動について，実験条件と観察眼 を要因とする分散分析を行った結果，屈折值では，有意 差は認められなかった（図9）。一方，調節微動では，観 測眼で有意傾向 $(\mathrm{p}<.10)$ が, 交互作用で有意差 $(\mathrm{p}<.05)$ 
が認められた（図10）。

\section{5. 実験 2 ：空間多重方式のアーチファクトの 評価}

\section{5-1. 方法}

空間多重方式のアーチファクトによる生体影響の評価 においても，実験1と同様の環境を構築し，同一の心理・ 生理指標をそれぞれ測定した。刺激の呈示には，偏光フ イルタが貼付された 22 インチの液晶モニタ（W220S， HYUNDAI IT) と, 円偏光フィルタメガネを用いた。モ 二タの解像度は $1680 \times 1050$ ピクセルであった。

実験条件は，アーチファクトの強度や種類を変化させ た4条件であったが，空間多重方式ではファントムアレイ は生起されないため, 全条件の視標の移動速度を 5 度/秒 とした (表2)。条件1では, 視野闘争, 偽視差, 解像度 低下の 3 種類のアーチファクトを含むよう, 視標の上辺と 下辺をそれぞれ片眼のみに呈示することで，視野闘争の

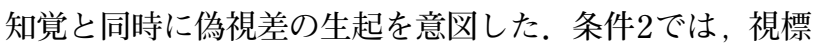
の欠損を補完することで，視野闘争の抑制を図った。条 件3では，記録時の左右の時間差によって発生する偽視差 を抑制するため，プログレッシブ型で呈示した．条件4で は，偏光メガネ側のフィルタの角度を調節し，あえて左 右の分離を不能にすることで, 解像度の低下を除去した 統制条件とした。

\section{5-2. 結果}

主観指標，客観指標共に時間多重方式と同様の解析を 行った. 刺激呈示後の眼精疲労の自覚症状について, 条 件別の結果を図11に示した。実験条件と自覚症状を要因 とした分散分析を行った結果, 実験条件の主効果 $(\mathrm{p}<.01)$ ，自覚症状の主効果 $(\mathrm{p}<.01)$ および交互作用 $(\mathrm{p}<.01)$ が認められた。 下位検定の結果, 条件1が他の 条件よりも，有意に上昇率が高いことが分かった。また， 上昇率の高い自覚症状の項目は, 実験1と同様の「目が疲

表2 空間多重方式の実験条件と3Dアーチファクト

Tab. 2 Experimental conditions and including 3D artifacts : spatial-multiplexing system.

\begin{tabular}{|c|c|c|c|c|c|}
\hline 空間多重 & 左右視標 & 視標速度 & 視野闘争 & 偽視差 & 解像度低下 \\
\hline 条件1 & $\square \square$ & 5度/秒 & あり & あり & あり \\
\hline 条件2 & $\square \square$ & 5度/秒 & なし & あり & あり \\
\hline 条件3 & $\square \square$ & 5度/秒 & なし & なし & あり \\
\hline 条件4 & $\square \square$ & 5度/秒 & なし & なし & なし \\
\hline
\end{tabular}

れている」「目がしみる」「目が乾いた感じがする」「目が ちかちかする」「目がしょぼしょぼする」という5 項目で あった。偽視差の強度の検討を目的とした，2D視標の立 体感の結果を図12に示した。実験条件を要因とした分散 分析を行った結果，有意差が認められ $(\mathrm{p}<.01)$, 下位検 定の結果, 条件 1 と条件 2 立体感が有意に高いことが分 かった.

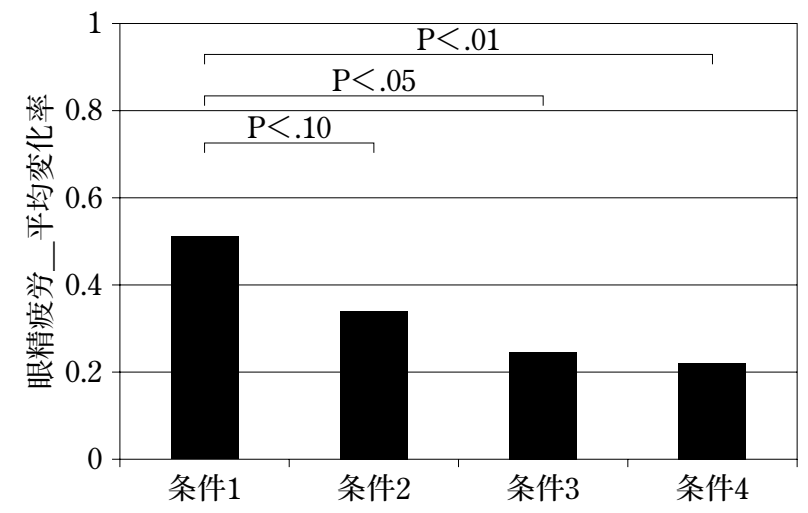

図 11 空間多重方式に打ける眼精疲労の自覚症状結果

Fig. 11 Result of visual fatigue subjective symptom : spatialmultiplexing system.

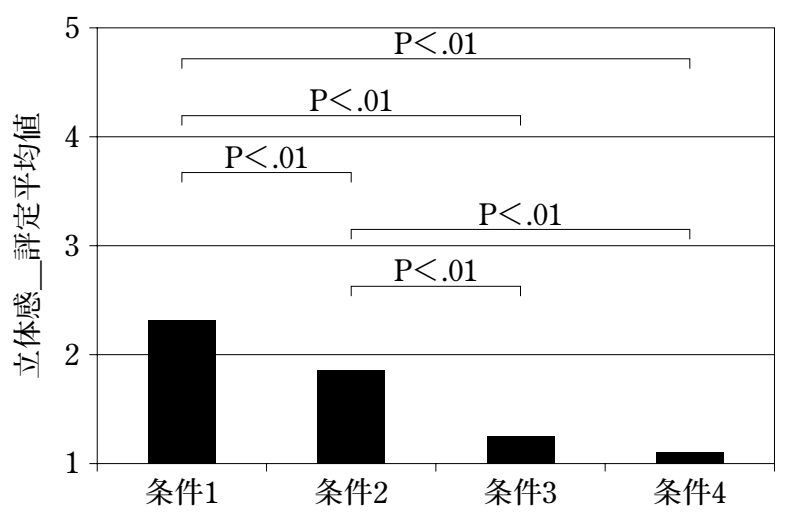

図 12 空間多重方式における2D指標の立体感の結果

Fig. 12 Result of depth sensation : spatial-multiplexing system.

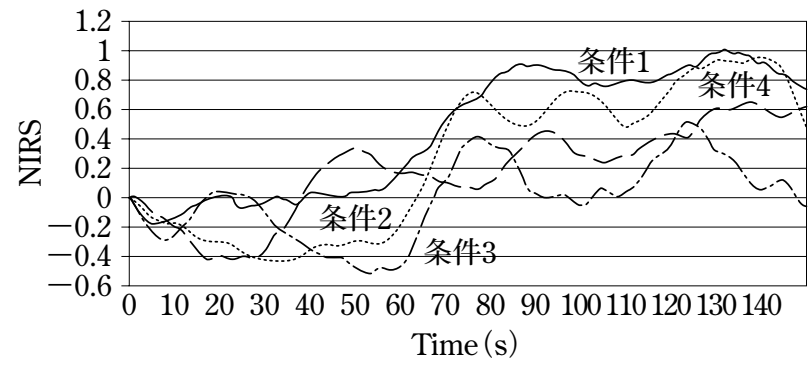

図13空間多重方式におけるNIRS值の結果

Fig. 13 Result of NIRS value : spatial-multiplexing system. 


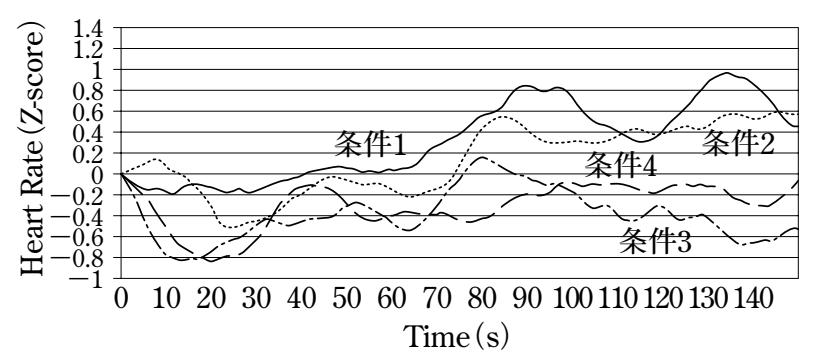

図14 空間多重方式における心拍動の結果

Fig. 14 Result of Heart Rate (Z-score) : spatial-multiplexing system.

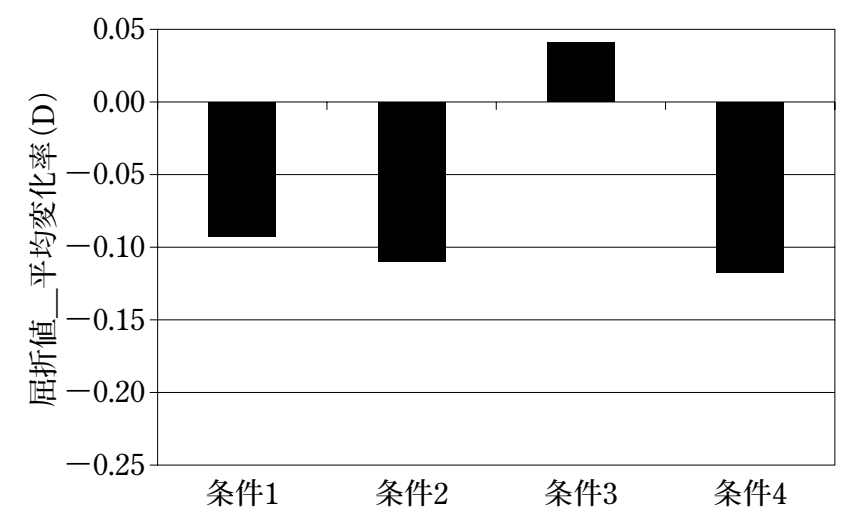

図15空間多重方式における屈折值の結果

Fig. 15 Result of refractive value : spatial-multiplexing system.

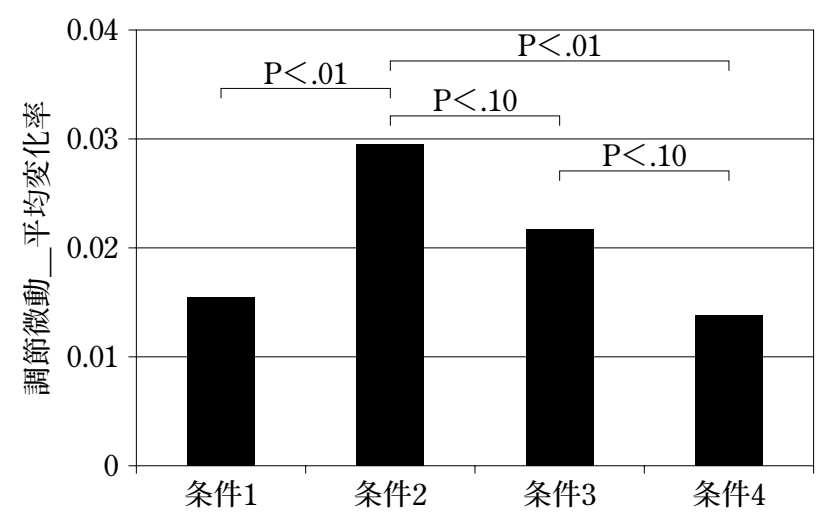

図16 空間多重方式に打ける調節微動の結果

Fig. 16 Result of accommodation value : spatial-multiplexing system.

脳血流について, 刺激呈示開始から150秒間のNIRS值 の変動を，図13に示した。実験条件と測定時間を要因と した分散分析を行った結果, 実験条件の主効果 $(\mathrm{p}<.01)$, 測定時間の主効果（ $\mathrm{p}<.01 ）$ が認められた。下位検定の 結果，条件1が他の条件より有意に高いことが分かった $(\mathrm{p}<.05)$ ，心拍動值の結果を図14に示す．脳血流と同様
に実験条件と測定時間を要因とした分散分析を行った結 果, 実験条件の主効果 $(\mathrm{p}<.01)$, 測定時間の主効果 $(\mathrm{p}<.01)$ が認められた。 下位検定の結果，条件 1 ，条件 2 が条件 $3 ， 4$ よりも有意に高いことが分かった $(\mathrm{p}<.01)$. 屈折值と調節微動について, 実験1と同様, ベースラインに 変換し，実験条件と観察眼を要因とする分散分析を行った。 結果から，屈折值では，有意差は認められなかった (図15)。 一方，調節微動では，呈示条件の主効果 $(\mathrm{p}<.05)$, 観察 眼の主効果（ $\mathrm{p}<.05 ）$ および交互作用（p<.01）に有意 差が認められた。下位検定の結果，条件 $2 か ゙$ 他の条件と比 べ，有意に上昇していることが分かった（図16）.

\section{6. 考 察}

時間多重方式では，眼精疲労の自覚症状に関して，ア 一チファクトの強度や随伴の顕著な条件 1 が，他の条件に 比べて有意に上昇した。この要因として，条件1のみに呈 示された 20 度／秒という，サッカードの誘発を意図した $2 \mathrm{D}$ 視標の高速な移動と，それによって生起されるファン トムアレイが関与していると考えられた。また，脳血流 や心拍動についても，条件1の上昇が最も高かったことか ら，アーチファクトの強度や随伴によって認知的負荷が 上昇し，神経細胞の活発化や交感神経の賦活が生じたと 考えられた。なお，刺激呈示後にインタビューを行った 結果，「白いラインの残像が知覚された」といった，ファ ントムアレイの生起に関連する回答が 28 例中 12 例で得ら れた．2D視標の立体感の結果と合わせて考察すると，条 件 $2 も$ 高い上昇傾向を示していることから，偽視差という 本来，2Dの視覚刺激に含まれない両眼視差による影響も 示唆された。また，条件 2 と条件 3 の間で，立体感に有意 に差があったことから，時間多重方式における偽視差は， 中間フレームを加えて呈示することで，軽減できること が分かった。さらに，今回の実験条件において，眼精疲 労の自覚症状や立体感に対して, 液晶シャッタメガネの フリッカの影響は，ほとんど認められなかった。これは， 液晶シャッタメガネの開閉が，臨界フリッカ周波数を超 える，十分に高速であったためと考えられた。ただし脑 血流において，全体では有意な差は見られなかったもの の，特定の時間においてフリッカを含む条件 3 高い上昇 傾向を示していたため，フリッカが生理的な影響を与え 得る可能性も否定できない.

空間多重方式では，眼精疲労の自覚症状に関して，時 間多重方式と同様，アーチファクトの強度や随伴の顕著 な条件1が，他の条件と比べて有意に上昇した。また，脳 血流や心拍動も条件1が高い上昇傾向を示していた。この 
要因として, 条件1のみに呈示された, 視野闘争を意図し た視標が関与していると考えられた。刺激呈示後にイン タビューを行った結果, 「左右の映像が一つの視標として 見えずにチラついた」などの視野闘争の生起に関する回 答が，28例中 13 例で得られた. 刺激呈示後の内省報告か らも確認することができた．2D視標の立体感の結果と合 わせて考察すると, 条件 2 も眼精疲労の自覚症状, 心拍動 が上昇する傾向がみられたため, 偽視差の強度による影 響も示唆された。また, 条件 1 と条件 $2 て ゙$, 立体感に差が 生じたことは, 視野闘争が奥行き知覚を生起するという, Sieve effect ${ }^{9)}$ に起因するものと考えられた. 加えて, 条 件 2 と条件 3 の間で, 偽視差の立体感に有意差がみられた ことから, 空間多重方式ではライン間での時間差を抑制 するプログレッシブ型で表示することで, 偽視差を軽減 可能であることが分かった。さらに，今回の実験条件に おいて, 眼精疲労の自覚症状や立体感に対する解像度の 低下の影響は, ほとんどみられなかった。一方, 調節微 動では，条件 2 において高周波成分の出現頻度が上昇する 結果となった。調節緊張が起きると, 調節微動の高周波 成分の出現頻度が高くなることが知られている ${ }^{10)}$ が, 変 化率の值が 0.015 ０.03という非常に微小な值域に収まっ ていることや, 他の心理・生理指標との相関が低いこと を考虑すると，本研究で設定した範囲においては，調節 緊張の影響はほとんどみられなかったと考えられた。

心理指標と生理指標の結果を合わせて考察すると, ア 一チファクトの強度や随伴が顕著になるほど, 生理・心 理的側面に扔いて，ネガティブな影響を与え得る可能性 が示唆された。加えて, アーチファクトの種類によって, 生体に与える影響が異なることも示唆された。また，今 回の実験条件では，アーチファクトが加算されていく形 となっているため、アーチファクト毎の特性や交互作用 は検討できていない。しかし，刺激に含まれるアーチフ アクトの種類が増加することで, 生理・心理的な変化が 顕著になったことから, 各アーチファクトが何らかの影 響を及ぼし得るとともに，アーチファクト間で相乗効果 が生じる可能性も示唆された。

\section{7. まとめ}

本研究では, 3Dの呈示方式によって生じるアーチファ クトの生体影響について，2D視標を用いて実験的な検討 を行った。結果から，時間多重方式と空間多重方式に打 いて，それぞれ特有のアーチファクトの生起を確認し， それらによる生理・心理的な影響について基礎的な知見 を得ることができた。具体的に, 時間多重方式では高速
な視標移動に伴うファントムアレイ, 空間多重方式では 左右眼の網膜像の差異による視野闘争というアーチファ クトが心理・生理的変化に大きく関与したと考えられた。 また，偽視差による立体感の生起と，それに伴う眼精疲 労の自覚症状の上昇も認められたことから, アーチファ クトの強度や種類の増加による影響の変化も示唆された. 一方で, 刺激の呈示方法を工夫することで, 特定のアー チファクトを抑制できることも分かった.

なお，本研究では測定に伴う負担を軽減するために， 簡易型NIRSを使用し，総へモグロビン量（total-Hb）を 測定した。しかし，一般にストレス刺激などで認知負荷 が高くなると, 脱酸素化へモグロビン (deoxy-Hb) が減 少し，酸素化へモグロビン（oxy-Hb）が上昇する ${ }^{11)}$ と言 われていることから，へモグロビン量を個々に計測した 場合，より明確な結果が出た可能性も考えられる．加え て, 簡易型NIRSで測定可能な前頭前野は，高次な処理を 行うことが知られており，アーチファクト以外の要因が 結果に影響した可能性もある。したがって，この知見を さらに深めていくためには, 脳血流の測定部位も検討す る必要がある。

最後に, 本研究の実験では2D視標による単純刺激を用 いたが，実際の3Dコンテンツを用い，実環境を考虑した 際のアーチファクトと生体影響との関連性についても併 せて検討を行うことで, 安全で快適な3Dの利活用に貢献 していきたい.

\section{謝 辞}

本研究の推進にあたり，(財)放送文化基金の助成を受 けた。ここに感謝の意を表す。

\section{参考文献}

1） JEITA 社団法人電子情報技術産業協会：3次元映像に 関するガイドライン試案, 2010.

2） $3 \mathrm{D}$ コンソーシアム：人にやさしい $3 \mathrm{D}$ 普及のための 3DC安全ガイドライン, 2010.

3）磯野春雄, 安田稔：時分割立体視の成立条件, テレビジ ヨン学会誌, 41 (6), 549-555, 1987.

4) Hershberger, W. : Saccadic eye movements and the perception of visual direction. Percept, Psychophysics, 41, 35-44, 1987.

5) Michaels, C. F., et al. : An onset to onset rule for binocular integration in the Mach-Dvorak illusion, Vision Research, 17, 1107-1113, 1977.

6）大野さちこ,鵜飼一彦：Head Mounted Displayをゲー ムに使用して生じる動摇病の自覚評価, 映像情報メディア 学会誌, 54 (6), 887-891, 2000.

7) 半田知也: 立体映像注視時の視覚反応: 生体反応計測 のアプローチ, 映像情報メディア学会技術報告, 34 (24), 
19-23, 2010.

8）三家礼子, 盛川浩志, 栗原俊介, 河合隆史, 田村義保：時 系列解析によるNIRSデータの信号処理, ヒューマンイン タフェース学会, 11 (2), 163-172, 2009.

9) Howard, I. P. : Depth from binocular rivalry without spatial disparity, Perception, 24, 67-74, 1995.

10）鈴木説子, 梶田雅義, 加藤桂一郎：調節微動の高周波成 分による調節機能の評価, 視覚の科学, 22 (3), 93-97, 2001.

11）福田正人：精神疾患と NIRS-光トポグラフィ検査による 脳機能イメージング, 22-27, 中山書店, 2009. 